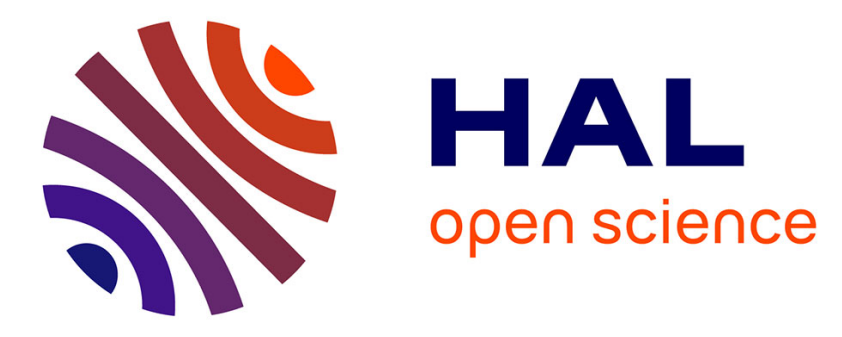

\title{
Hydraulics and bridges: A French case study of monitoring of a bridge affected by scour
}

Frédérique Larrarte, Christophe Chevalier, Louis Battist, Hugues Chollet

\section{To cite this version:}

Frédérique Larrarte, Christophe Chevalier, Louis Battist, Hugues Chollet. Hydraulics and bridges: A French case study of monitoring of a bridge affected by scour. Flow measurement and instrumentation, 2020, 74, 10 p. 10.1016/j.flowmeasinst.2020.101783 . hal-02933658

\section{HAL Id: hal-02933658 \\ https://hal.science/hal-02933658}

Submitted on 8 Sep 2020

HAL is a multi-disciplinary open access archive for the deposit and dissemination of scientific research documents, whether they are published or not. The documents may come from teaching and research institutions in France or abroad, or from public or private research centers.
L'archive ouverte pluridisciplinaire HAL, est destinée au dépôt et à la diffusion de documents scientifiques de niveau recherche, publiés ou non, émanant des établissements d'enseignement et de recherche français ou étrangers, des laboratoires publics ou privés. 


\title{
Hydraulics and bridges: A French case study of monitoring of a bridge affected by scour
}

\author{
Frédérique Larrarte Ph. D. Senior researcher ${ }^{\mathrm{a}, \mathrm{b}, *}$, Christophe Chevalier ${ }^{\mathrm{a}}$, Louis Battist ${ }^{\mathrm{a}}$, Hugues Chollet $^{\mathrm{c}}$ \\ ${ }^{a}$ GERS, Univ. Gustave Eiffel, IFSTTAR, F-77447, Marne La Vallée, France \\ ${ }^{\mathrm{b}}$ LHSV, 6 Quai Watier, 78401, Chatou, France \\ c COSYS, Univ. Gustave Eiffel, IFSTTAR, F-77447, Marne La Vallée, France
}

\section{A R T I C LE IN FO}

Keywords

Monitoring

Hydraulics

Field study

Scour

\begin{abstract}
A B S T R A C T
Bridges are one of the oldest types of civil engineering structures and the interaction between the transport and hydrographic networks represents a significant issue in a country such as France. Recently, various cases highlight the importance and vulnerability of civil transport works in relation to their environmental hazards, e.g. floods, and therefore the need to develop integrated observation tools and warning systems in the aim both of optimizing the management system and of increasing the knowledge on real scour processes. This paper reports on the "field approach" task of a research project aiming at improving continuous monitoring in order to follow the evolution of the scour processes of a given bridge or abutment. The first step has been to identify a pilot site, representative of scour vulnerability. After a report of the scour parameters to be monitored, the benchmark study and the choice of monitoring devices available on the market are detailed. Instrumentation, sensor adaptability, limitations (actual measurement ranges, ergonomics, energy supply limits ...) and in situ implementation are then presented and discussed. Finally, preliminary measurements, post-treatments and interpretation are detailed.
\end{abstract}

\section{Introduction}

As most civil structures like bridges in or adjacent to watercourses are subjected to the problem of scour, the interaction between the transport and hydrographic networks represents a significant issue in a country such as France. A flood event in 2009 in the city of Bayonne paralyzed road traffic for an extended time due to instability and consequently led to closing the Mayou Bridge, where inspections two years prior had failed to detect any problems. The collapses of the Wilson Bridge in Tours in 1978 and St Louis Bridge on Reunion Island in 2007 or, more recently, the destruction of the Coarraze railway embankment on the Gave de Pau River in 2013 are other few examples. Those cases highlight the importance and vulnerability of civil transport works in relation to environmental hazards.

Scouring is the erosive action of sediments due to eddies generated in a river or marine current encountering natural (concave bank of meanders) or artificial obstacles (bridge piers, jetty ...). Because of the enormous stakes involved, scour has been studied for a long time. Thus, in 1873, Durand Claye [1] already did various experiments and concluded that "having an upstream shape like a triangle and a rounded downstream shape could be a practical and rational solution". With the $\mathrm{XX}^{\text {th }}$ century, the research effort has increased worldwide and, according to Breusers et al. [2], the equilibrium scour depth at bridge pier can be estimated by the general relation (1)

$d_{\text {se }}=f\left(\rho, \mu, U, h, g, d, U_{c}, D\right)$ where $g$ is the acceleration of gravity; $h$ is the depth of water; $U$ is the average upstream velocity; $\mathrm{D}$ is the typical dimension (e.g. diameter) of the pile, $\rho$ is the density; $\mu$ is the dynamic viscosity of the fluid, $U_{c}$ is the critical value of the velocity associated with the movement of the bed particles, $\mathrm{d}$ is the typical dimension (e.g. mean diameter) of the particles. Various laws have been proposed to predict the scour depth [3-5] even by taking account of the temporal aspect [6]. In the same time, in various countries, guidelines [7-16] have been published to explain the phenomenon, provide design rules and dimensioning laws to engineers and practitioners.

Twenty years ago, Hamill [17] has made a large review of interactions between bridges and hydraulics with a well documented historical point. He pointed that, betwwen 1847 and 1973, about half of the bridge failure he reported were related to scour. It can be noticed the London Bridge photography showing that this bridge, built in the XIIth century, has already an upsteam shape like a triangle or like a maritime ship and not a round shape like the upstream shape of many piers used during laboratory experiments. For their part Melville and Coleman [18] have presented a complete state of the art about scour with various feedback from New Zealand rather new bridges. Both have presented many elements about design rules. However, about a third of a century later, Sheppard et al. [19] have shown that each of the existing laws has its own limitations.

One of the reason is, as explained by Ettema et al. [20], that scour phenomenon is a combination of several processes: "Although much design progress has been made during the last 60 years, scour continues as a leading cause of 
bridge failure". A complementary method for managing structures, in particular existing ones, is by making regular surveys or even better continuous monitoring. This will lead to both a better understanding of scour phenomena and optimized recommendations for practitioners and owners dealing with scour risk.

Monitoring techniques need to be able to handle one or several of the main measurands listed in equation (1). As scour can be defined as the excavation and removal of the material from the bed and banks of stream as a result of the erosive action of flowing water, a key issue to understand the physics of the phenomenon on a given site is thus to measure the water level and, if possible, the flow velocity. Water level measurements are commonly used and generally made by using limnimetric gauging station, radar techniques or transit time ultrasonic techniques to review the most usual methods. Nowadays, the data transmission techniques allow to record data and then to follow automatically the hydraulic situation by the measurements of the water level. Water (maximum/surface/typical ...) velocity and/or discharge can then be evaluated by the use of rating curves. For precise measurements of velocity, ADCP (acoustic Doppler Current profiler) techniques are commonly used for more than 20 years now [21]. ADCP apparatus allow to record velocity fields and, in particular, to have access to flow properties in the vicinity of sediment bed layer. However, usually only short time measurements survey are practiced due to the quite expensive price of such device. So these ADCP techniques are not commonly used for monitoring even if Tapia Rodriguez et al. [22] present cases study within a review of velocity measurement devices.

The complementary measurements for following scour phenomena are the sediment bed levels in the vicinity of the structure. Twenty years ago, Forbe et al. [23] already proposed to determine the sub bottom level close to a bridge with a radar when Schall \& Davies [24] tested a sonar and a magnetic collar. The potentialities of monitoring structural parameters such as vibration frequencies have also been investigated [25-28]. Various authors [29-34] have made recent point of available techniques and proposed more global views and recommendations focusing on bathymetric and vibration measurements but dealing only quite a little with the flow velocity.

This paper reports on the "field approach" task of a project [35]. The presented study thus aimed at providing an insight into the global monitoring of scour affecting an abutment. The first step of our study has been to identify the pilot site, representative of scour vulnerability, to review available data and to define requirement for the monitoring devices and structure adapted to the different situation. In situ implementation will then be presented with a focus on the preliminary measurements including data processing and post-treatments. Results and feedback after some months of instrumentation will finally conclude this paper.

\section{Site description and definition of the monitoring objectives}

Several criteria were defined to select real sites that would be monitored during either brief campaigns or for some longer continuous periods (as the site presented in this paper). These criteria were related to:

- representative sites on which scouring phenomena have been observed and are in progress,

- hydraulic-meteorological-geographical context,

- documented sites for which data are accessible (geometry, type of support, inspection and monitoring report, bathymetric, geotechnical, hydraulic data, etc.),

- rules and regulations.

- access for the experimental team (safety in particular on bridge with railway traffic but also transportation time from their main location)

. The selection has been done in collaboration with the French national network company, SNCF Réseau, teams. Using geographical information system tools and their databases [36], an inventory of the sites affected by scouring phenomena was carried out. It takes account of quite a large number of parameters. In small natural rivers like those we have in France, it proved difficult to avoid any bend or meanders.

\subsection{Description of the field site}

The railway bridge over the Aurence is a characteristic arch bridge built on the banks of the channels. It is representative of the structures of secondary road and rail networks and it is located on the railway line linking Limoges to Angoulême. Just in that region of France there are about 3000 bridges similar to the chosen one. Traffic consists of commuter trains and freight trains, including those from a quarry that provides ballast, particularly for bullet train lines. The bridge is a masonry rail bridge with shallow foundations. It has been built about 1880 and it is also very similar to some of the presented by Ref. [17] in United Kingdom.

The French National database "Banque Hydro" (http://www.hydro. eaufrance.fr/) has a gauging station located $3 \mathrm{~km}$ upstream. This station is located $230 \mathrm{~m}$ above the sea level and records Aurence flow rate since 1995. Fig. 1 shows the variations of the monthly flowrate from September 2015 to July 2019. The river is located into the oceanic climate zone with high flow rates in winter and low flows in summer. Strong variations with lower values in summer can be observed as well as inter annual ones. In this small catchment, whose area equals $87 \mathrm{~km}^{2}$, the highly rainy month of January 2018 can also be seen. The Aurence catchment it is very reactive with a flood duration of approximately $24 \mathrm{~h}$. The peak discharge of the highest floods that appeared on the river during the last 25 years was about $28 \mathrm{~m}^{3} / \mathrm{s}$ in February 2003. The return period of this flood is estimated at twenty years.

\subsection{Bathymetry survey}

This site is affected by scour on the abutment. The wall is partly collapsed and many blocks in the riverbed come from it (Fig. 2). At the foot of the abutment, we measured a scour of $1.7 \mathrm{~m}$ long and $0.5 \mathrm{~m}$ deep (Fig. 3). A bathymetric campaign made with pointing gauge has confirmed that an eroded area exists under the bridge with an even deeper part at the extrados of the bridge (dark blue part on Fig. 3). It has been decided to implement the sensors on that area (red circle on Fig. 3). A granulometric analysis of the sediment has shown that we have sand over $0.1 \mathrm{~mm}$.

\subsection{Variables to be monitored}

Regular surveys are an interesting tool to globally know the hydraulics and sediment transport of a river but they cannot catch all its dynamics especially considering that scour is an active phenomenon including erosion and deposition processes.

As underlined in the introduction, the objective of the monitoring was thus to have a continuous measurements of both hydraulics properties and bathymetry. These include: water level, velocity profile, and sediment level or bathymetry. For each measurand, the following items have been taken into account:

- min-max measuring range,

- desired characteristics (uncertainties, resolution, ...),

- intrusiveness,

- innovative techniques/more robust techniques,

- homogeneity of a fleet of equipment (on 1 site if redundancy or between sites),

- equipment acquisition costs,

- operating and maintenance costs,

- data recovery costs,

- on-site deployment constraints,

- installation constraints,

- power supply (mains, battery, if batteries what autonomy ...),

- post processing (validation criteria, operation, ...) ... 


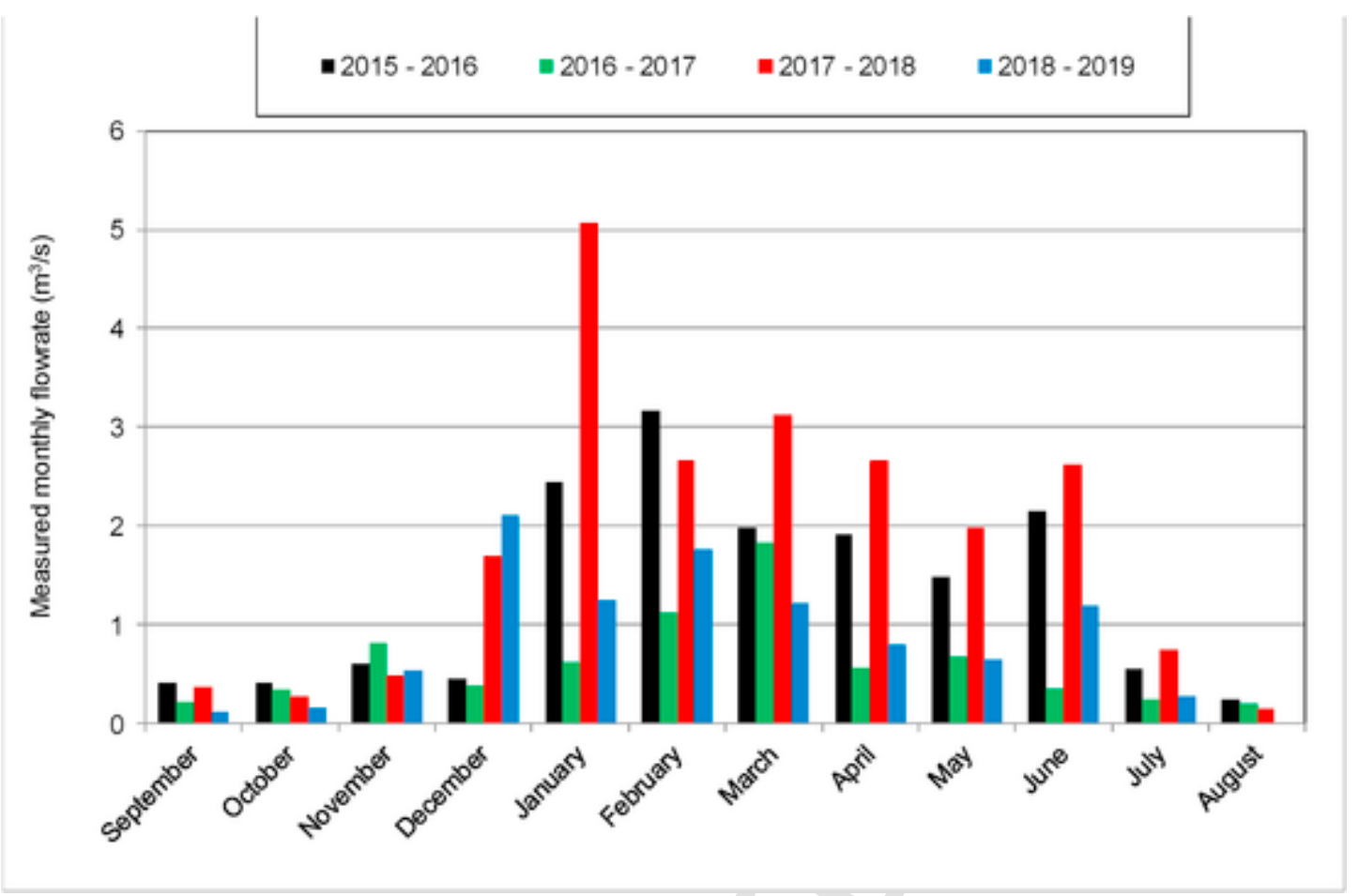

Fig. 1. Aurence river - Monthly flow rate variaations.

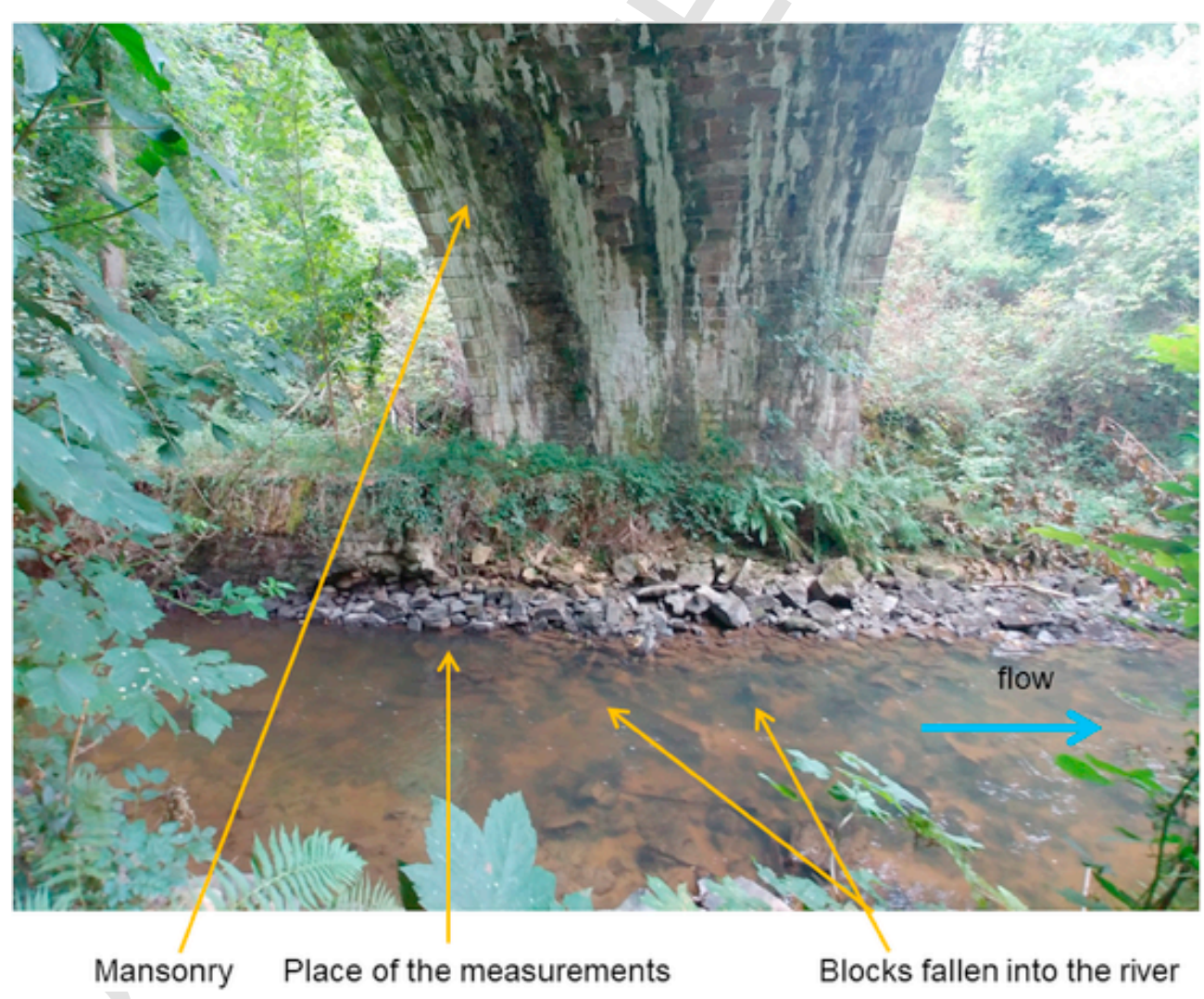

Fig. 2. View of the Aurence abutment site. 

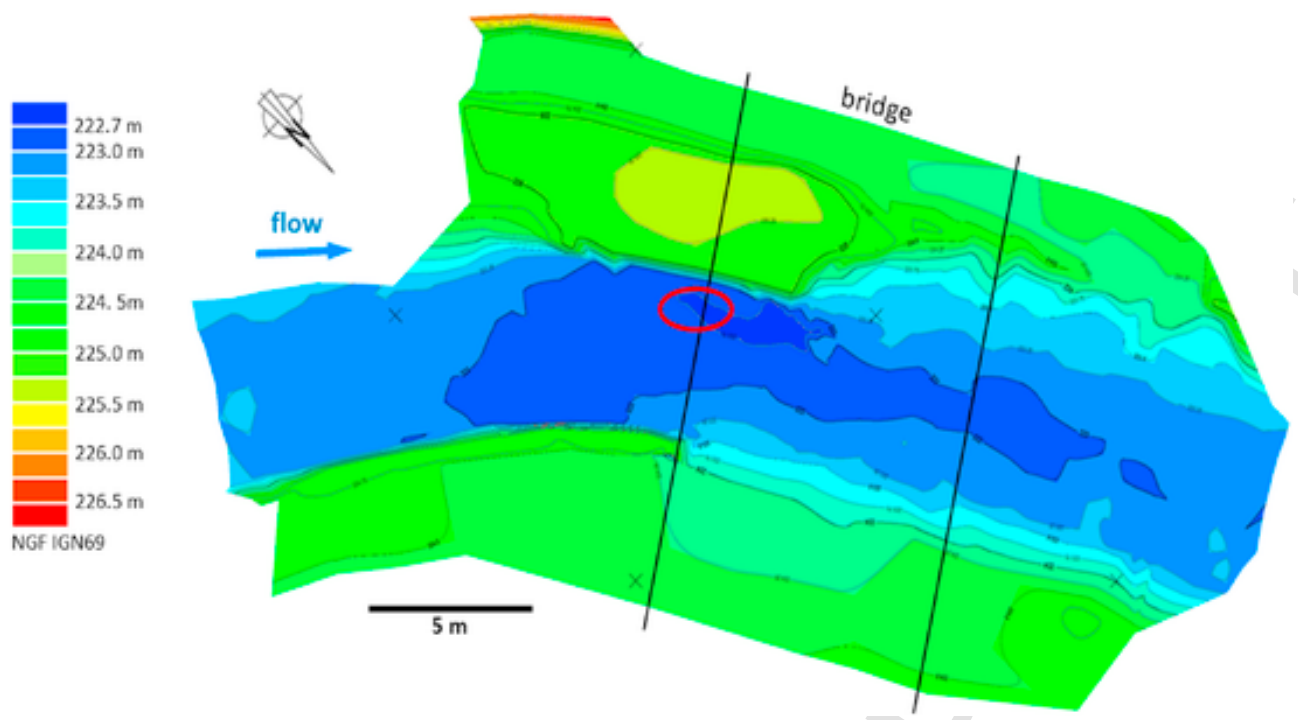

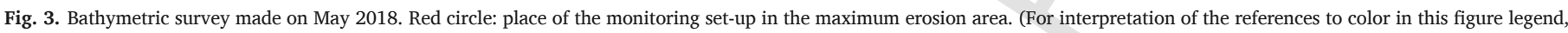
the reader is referred to the Web version of this article.)

\subsection{Constrain and criteria of selection for the devices}

Using the preliminary knowledge of the site, Tables 1 and 2 list some of the specifications sent to suppliers in order to monitor the site. These specifications cover the different aspect of monitoring: specification

of

devices

(Table

Table 1

Specifications sent to suppliers in order to monitor the site.

\begin{tabular}{lll}
\hline $\begin{array}{l}\text { Parameter or } \\
\text { function }\end{array}$ & Range & Technical proposals \\
\hline Flow velocity & $0.2-1.5 \mathrm{~m} /$ & Velocity profiler (1D) \\
Water level & $0-2 \mathrm{~m}$ & $\begin{array}{l}\text { Distance from free surface to } \\
\text { bottom + reference from free surface to } \\
\text { bridge } \\
\text { Altimeter? } \\
\text { Lathymetry } \\
\text { measurements }\end{array}$ \\
$0.3-1.5 \mathrm{~m}$ & $\begin{array}{l}\text { Localization of the vertical position of the } \\
\text { sediment surface? }\end{array}$ \\
\hline
\end{tabular}

Table 2

Control and installation specifications.

\begin{tabular}{|c|c|c|}
\hline $\begin{array}{l}\text { Parameter or } \\
\text { function }\end{array}$ & Constrain & $\begin{array}{l}\text { Technical } \\
\text { proposals }\end{array}$ \\
\hline $\begin{array}{l}\text { Location of the } \\
\text { sensors }\end{array}$ & $\begin{array}{l}\text { At free surface to be as little intrusive as } \\
\text { possible or on a fix position but at least } \\
1 \mathrm{~m} \text { for the sediments to avoid local scour } \\
\text { Measurement head remaining at a given } \\
\text { position (horizontal plane) to investigate } \\
\text { the temporal evolution of the bottom }\end{array}$ & On a raft \\
\hline $\begin{array}{l}\text { Fixation/position } \\
\text { on the sites }\end{array}$ & $\begin{array}{l}\text { Sensors following the variations of the free } \\
\text { surface }\end{array}$ & $\begin{array}{l}\text { Vertical } \\
\text { movement }\end{array}$ \\
\hline Protection & $\begin{array}{l}\text { Limit the embedded materials avoid to } \\
\text { disturb the measurements }\end{array}$ & $\begin{array}{l}\text { Upstream } \\
\text { shape of the } \\
\text { raft }\end{array}$ \\
\hline $\begin{array}{l}\text { Recording } \\
\text { frequency }\end{array}$ & Can be chosen & User chosen \\
\hline Energy & Minimize maintenance & $\begin{array}{l}\text { Batteries and } \\
\text { solar panels }\end{array}$ \\
\hline Data transmission & Minimize maintenance & $\begin{array}{l}\text { Tele } \\
\text { transmission }\end{array}$ \\
\hline Set-up supervision & $\begin{array}{l}\text { Permanent view of the set-up and generate } \\
\text { intervention in case of trouble }\end{array}$ & Camera \\
\hline
\end{tabular}

1) and installation (Table 2). Various technical proposals and constrains are also listed.

An inventory of existing devices has been done. It was conducted for countries whose context seems similar to the French hydro-geological one, which ranges from oceanic to Mediterranean climate through mountainous one, if we limit our present study to the metropolitan area, for practical reasons. The specifications have finally been sent to about fifteen suppliers either in France or abroad.

\subsection{Selected devices and installation}

One great challenge has been to test methodologies and materials that can be routinely implemented on structure and also to develop the data validation and analysis process. In the same time, studies have been conducted on the implementation of the instrumentation in such a way that it will be as little intrusive as possible in order to limit the disturbance of the flow. The choice has been made to focus on acoustic devices as acoustic waves are able to go through particle laden flows and then to measure when heavy erosion happens. ADCP might appear as convenient sensors however, due to construction, the beams encompass quite a large area and the calculation process of the velocities, their meaning can be questionable as pointed by Le Barbu et al. [37]. Moreover, those devices are rather heavy. Lighter profilers like the Ub-flow [38] may be an alternative, even if the transverse velocity is not evaluated. On this small river site, a rather light structure to measure above a fixed point was designed. Using an existing sailboard, whose shape seems adequate to minimize interactions with floating debris, the raft has been installed (Fig. 4a and b) and follows the water free surface variations with very little intrusiveness of the sensors.

It is thus theoretically possible to know if the river bed is eroded or not, using the same idea than Larrarte et al. [39]. The following devices have been implemented:

- an Ijinus LNU06V3-82-3G ultrasonic water level gauge to measure the water level, using the transit time principle,

- an ultrasonic Ub-flow UBF156 by Ubertone to measure the velocity profile and the water depth,

- a HIK Vision 4 MP WDR fixed network camera to watch the sensors periodically in order to identify any emergency situation.

The Ub-flow profiler is made to simultaneously measure the streamwise and vertical velocities. This sensor is constituted by two transducers: 


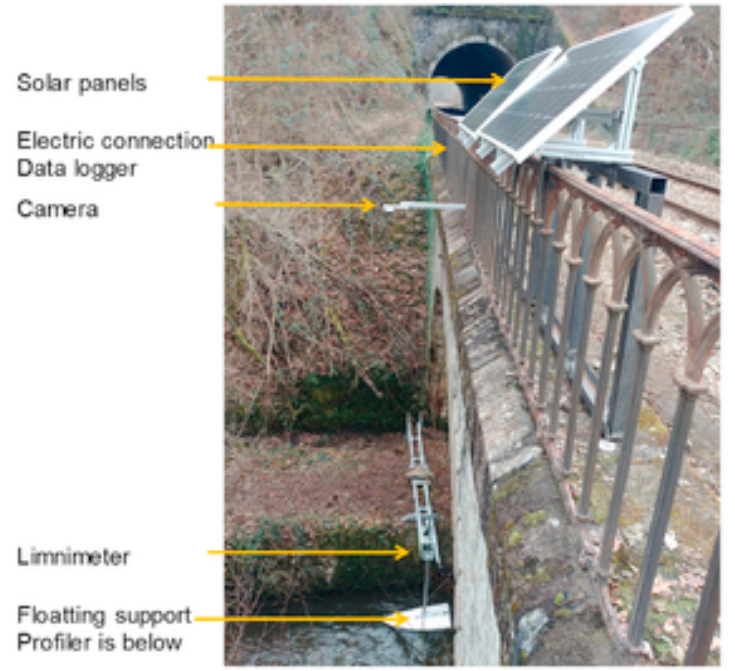

(a)

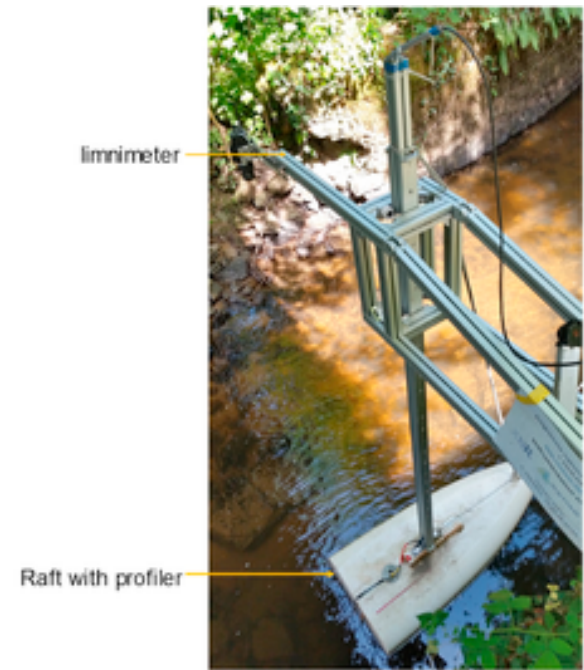

(b)

Fig. 4. Monitoring set-up installed on the abutment site: (a) General view of the instrumentation; (b) Detail of the raft.

one has an inclination angle of $65^{\circ}$ with regard to the Ub-flow base and an emission frequency centered on 1.5 MHz. The second transducer has an inclination angle of $97^{\circ}$ with an emission frequency centered on $3 \mathrm{MHz}$. This sensor configuration allows making a velocity profile with a spatial discretization up to $5 \mathrm{~mm}$ below the dead zone that is $5 \mathrm{~cm}$ long, and a transversal resolution of $10 \mathrm{~cm}$ [38].

\subsection{Bathymetric evolution: depth of erosion}

With the chosen set-up, the velocity profiler allows to localize the river bed (Fig. 5). Knowing the distance $h_{1}(t=0)$ between the limnimeter and the free surface and the water depth $h_{p}(t=0)$ at the initial time (when we implement the set-up) we can define the reference height $\mathrm{h}_{\text {ref }}$ by equation (2):

$\mathrm{h}_{\mathrm{ref}}={ }_{\mathrm{hp}}(\mathrm{t}=0)+{ }_{\mathrm{hl}}(\mathrm{t}=0)$

At any time later, distance $h_{l}(t)$ between the limnimeter and the free surface is measured continuously. It allows defining a water level relative to the initial state

$\mathrm{h}_{\mathrm{w}}(\mathrm{t})=_{\text {href }}-\mathrm{h}_{\mathrm{l}}(\mathrm{t})$

Comparing this water level $h_{w}(t)$ to the water depth $h_{p}(t)$ measured continuously with the velocity profiler allows to evaluate the scour equation (4):

$d_{s}(t)=h_{p}(t)-h_{w}(t)$

\section{Results}

\subsection{Water level}

The ultrasonic limnimeter records the water level every $5 \mathrm{~min}$. Results are depicted on Fig. 6. Small fluctuations can be observed and related to the natural fluctuations of a river free surface. Those fluctuations are smoothed as presented with the mean value over 21 values. It is interesting to notice that the dynamic is the same that on the gauging station of the Banque Hydro (see section 2.1), the constant gap of $0.22 \mathrm{~m}$ is due to the fact that the Banque Hydro station is related to a national reference and not to the local reference used for our project. Another interesting point is the great reactivity of the water level to the precipitations that vary from 0 to $45 \mathrm{~mm}$ in one day during the presented period (Fig. 6). It is also interesting to point the very low water levels observed in September, this month corresponds to the new hydrologic year.

\subsection{Bathymetry evolution}

The ultrasonic profiler is located at the free surface to prevent any interaction with the river bed. The backscattered signal amplitude allows locating the bed, as proposed by Ref. [38]. Fig. 7a represents the evolution of the backscat-

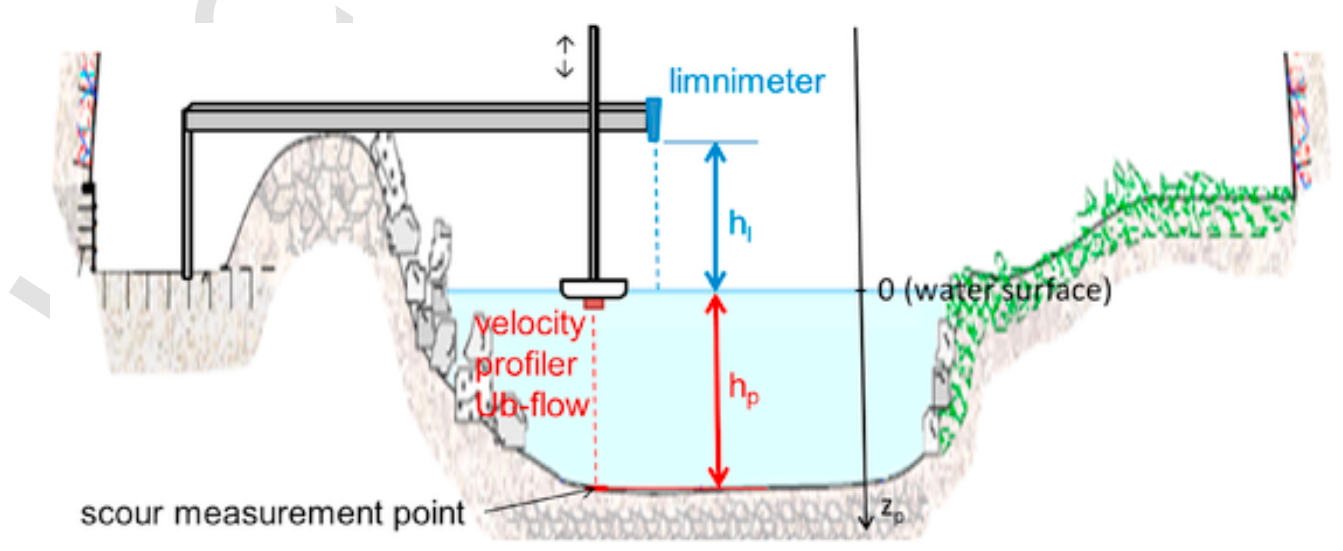

Fig. 5. Definition of the various heights. 


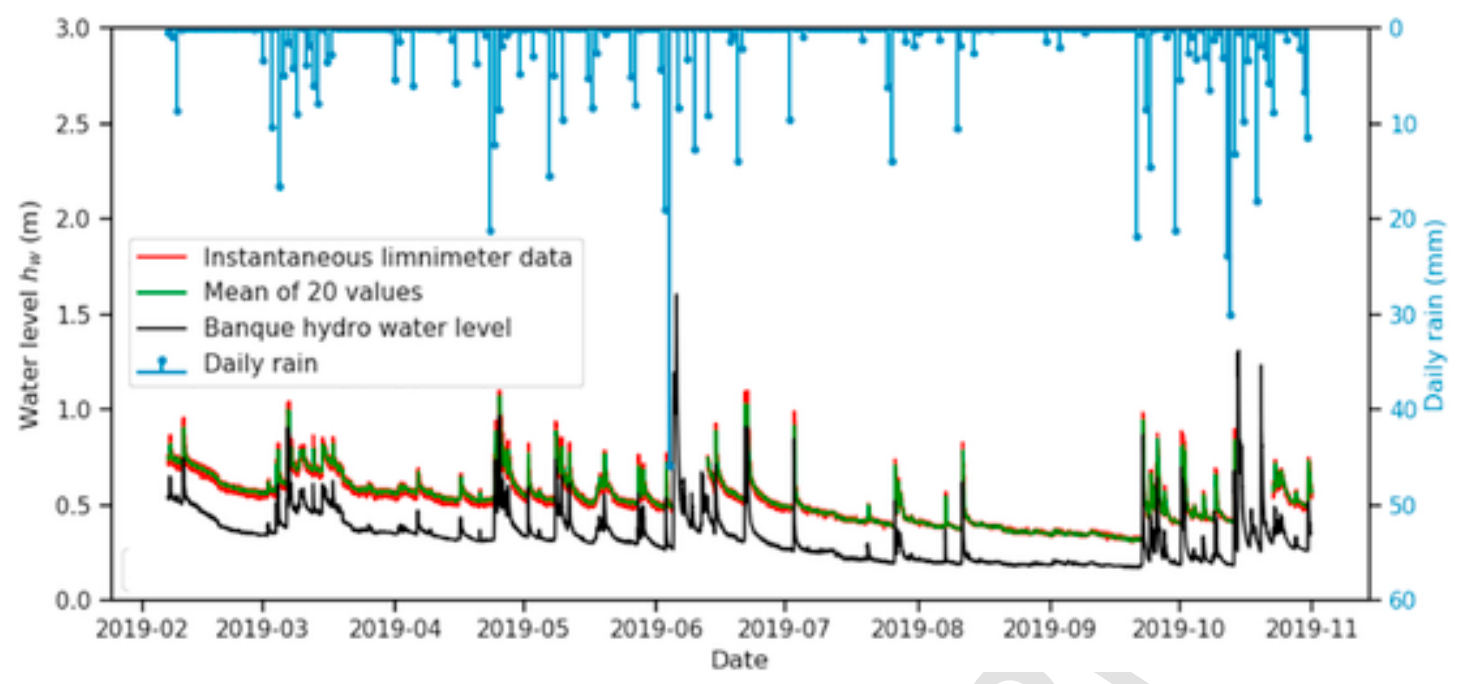

Fig. 6. Water level chronicles.

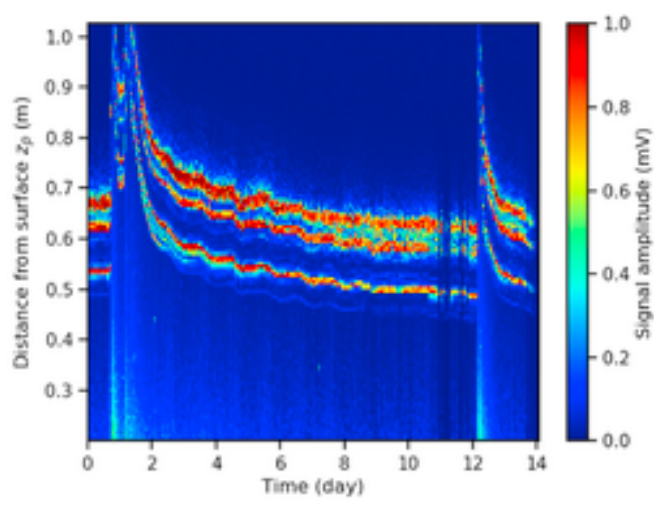

(a)

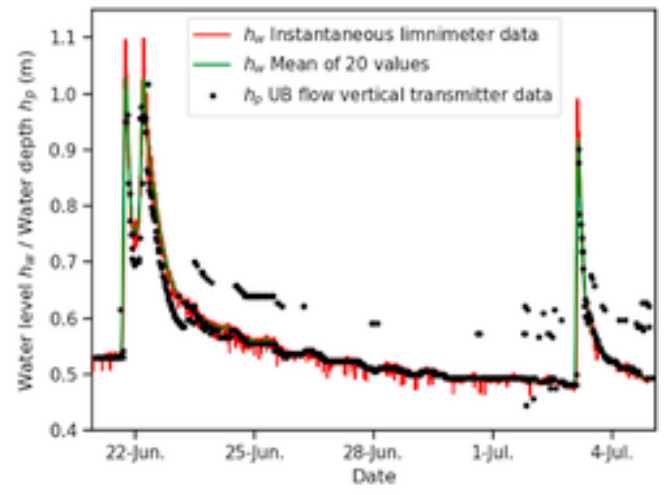

(b)

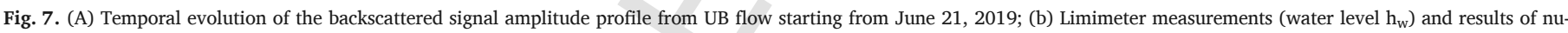
merical treatment of Ub-flow signal for determining the water depth $h_{p}$ as a function of time.

tered signal amplitude from the second acoustic transducer of the Ub-flow. This evolution is depicted as a function of depth (vertical distance $z_{0}$ from the surface - see Fig. 5) and time (starting from June 21, 2019). A high amplitude means the presence of an "acoustic obstacle" like the sediment surface (here mainly sand and some blocks). The sediment surface is interpreted as the first jump of amplitude. Fig. 7b represents data issued from numerical treatment (black point) and limnimeter data (presented in Fig. 6). A very good agreement is found confirming that it is possible to follow both the water level $h_{w}$ (from limnimeter data) and the water depth $h_{p}$ (from Ub-flow) as expected previously in section 2.6. Comparing both allows determining the real erosion or depositing level along the time. This comparison depends on the numerical treatment of the backscattered signal that can still be improved: due to multiple diffusion of the acoustic signal, it is sometimes difficult to localize precisely the sediment surface. Up to now, even after the Miquel storm (June 5, 2019), no significant difference was observed between $h_{w}$ and $h_{p}$, meaning that, as proposed by equation (3), no significant erosion of the bed at the vertical of the sensors occurred.

\subsection{Velocity}

Since the Doppler signal acquisition is sampled by nature, it is subject to Shannon's theorem which imposes a maximum measurable speed range (i.e maximum speed minus minimum speed) called Nyquist limit. This velocity range is directly proportional to the Pulse Repetition Frequency (PRF). The depth of acquisition is therefore directly related to the rehearsal period of the wave trains. This imposes the main limitation of this method, namely an inverse relationship linking depth and velocity [40]: as much the depth acquisition is large as small the velocity range would be. Thus two different configurations have been implemented:

- config 1: acquisition of mean velocity profile (from 300 successive instantaneous profiles) in the vicinity of the sensor (from 0.03 to $0.36 \mathrm{~m}$ depth and from -0.35 to $2.63 \mathrm{~m} / \mathrm{s}$ ),

- config 2: acquisition of instantaneous velocity profiles with different depth and velocity range acquisition (typically from 0.20 to $0.93 \mathrm{~m}$ depth and from -0.19 to $0.85 \mathrm{~m} / \mathrm{s}$ velocity).

The first configuration aims at having the higher velocities but the counter part is the measurements can only be made close to the sensor. The second configuration allows having the best compromise between depth and velocity but can be subjected to the Nyquist limit and thus numerical corrections have to be implemented. Due to this limitation, only instantaneous profiles can be acquired for this second configuration. An acquisition for all configurations is done every $5 \mathrm{~min}$.

Fig. 8a represents the temporal evolution of the instantaneous velocity profile (by config 2) as a function of depth (vertical distance from the surface) and time (starting from June 21, 2019). Due to restriction on velocity range (Nyquist limit), shifts on velocity values are observed when the local velocity is higher than the maximum one. However, a numerical post-treatment of the data allows replacing the values as it can be observed on Fig. 8b. It is then possible 


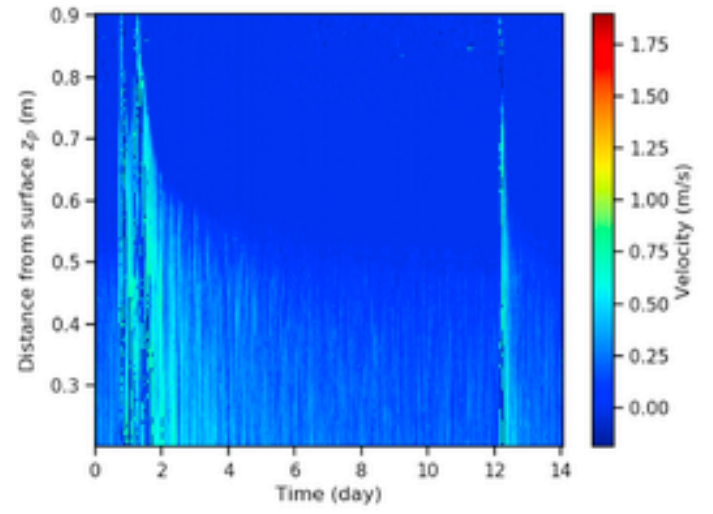

a)

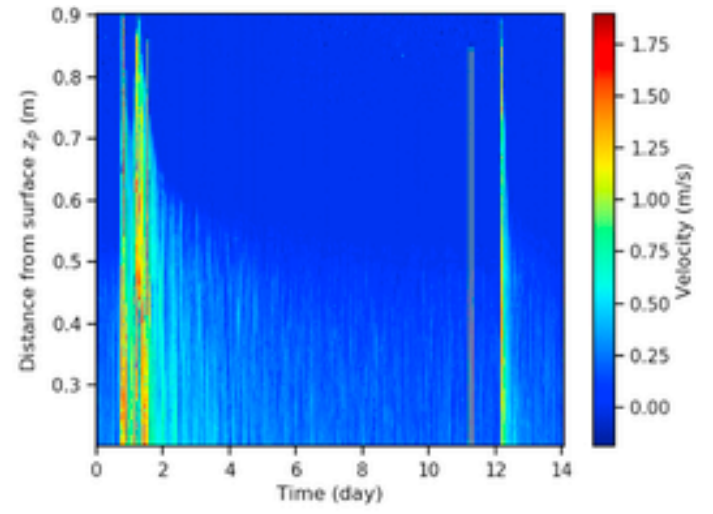

b)

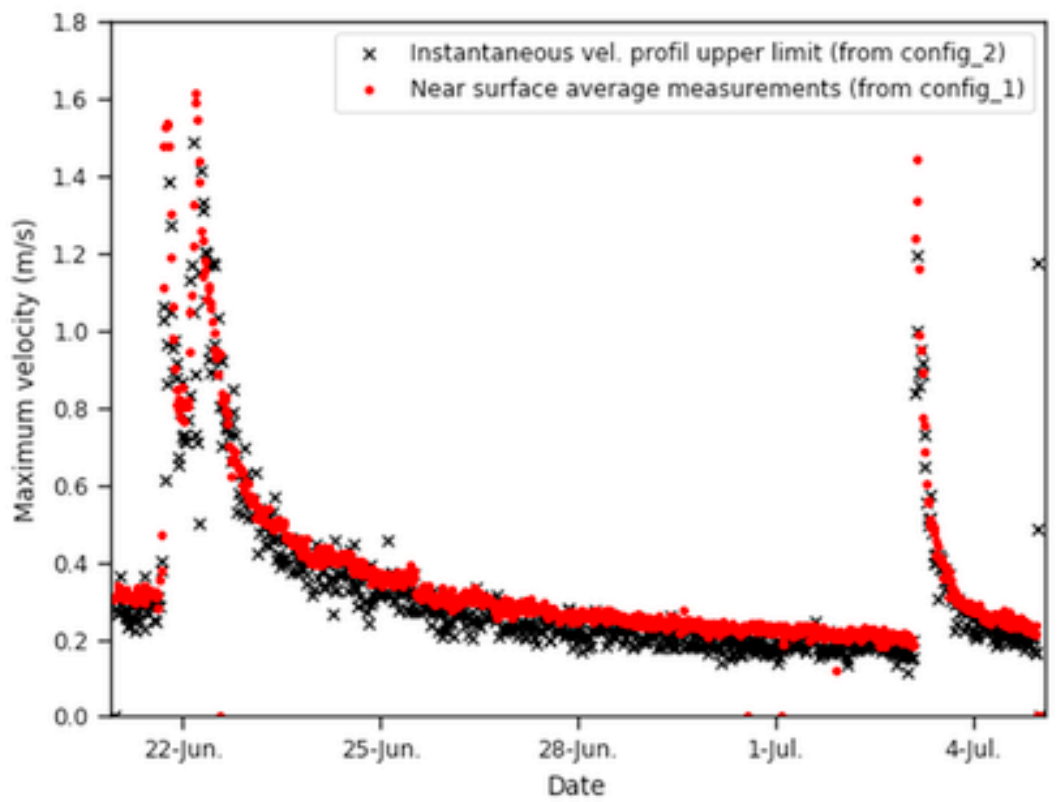

(c)

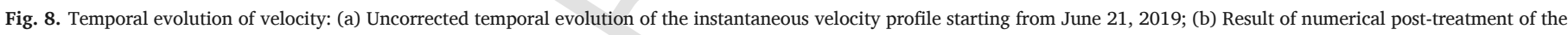
data; (c) Maximum velocities (from instantaneous or averaged profiles) as a function of time.

to evaluate the maximum velocities obtained in both afore mentioned configurations as depicted on Fig. 8c.

A rather good agreement is observed between both configurations. Moreover, the flow velocity (Fig. 8c) and the water depth (Fig. 7b) have very similar evolution. Whereas this observation is quite obvious, future data analysis on long term will allow obtaining and discussing on rating curves evolution specific to the site.

It is important to consider that continuous monitoring robustness depends of the capability to measure even during floods, it means when sensors are very highly strained by fast velocity and potentially heavy solid transport. The less intrusive the sensor is, the less risk it has of disturbing the flow but also of hanging with branches. In addition, a sensor on the surface is less prone to shock with possible elements carried by the current (stones). Also, it would be interesting to have only the surface speed to be measured and to have a scaling curve giving the shear velocity. At the same time, standard ISO 748 [41] indicates that the coefficient between the surface speed, taken as the maximum value, and the average speed, taken at $60 \%$ depth, is between 0.84 and 0.90 depending on the roughness. This shows the importance of learning about each site hydraulics with the entire velocity distribution to access the velocity in the logarithmic region, as a way to determine the shear velocity. Nikuradse [42] has proposed a logarithmic law (log law) to describe the vertical distribution of the mean streamwise velocity. To extend in the outer region, the velocity profile can be estimated by Coles equation (Equation (5)):

$$
\begin{aligned}
\frac{U}{u *} & =\frac{1}{K} \ln \left(\frac{z_{w}}{k_{s}}\right)+B_{s}+\mathrm{w}(\xi) \text { with } w(\xi) \\
& =\frac{2 \Pi}{\kappa} \sin ^{2}\left(\frac{\pi}{2} \xi\right)
\end{aligned}
$$

where $\mathrm{w}(\xi)$ is the wake function and $\Pi$ the wake parameter proposed by Coles [43] who introduced an additive correction to the log-law, $\mathrm{U}$ $\left(\mathrm{z}_{\mathrm{w}}\right)$ is the mean streamwise velocity measured at a distance $\mathrm{z}_{\mathrm{w}}=\mathrm{h}_{\mathrm{p}}$ $\mathrm{z}_{\mathrm{p}}$ from the bottom, h the water depth, $\xi=\mathrm{z}_{\mathrm{w}} / \mathrm{h}_{\mathrm{p}}$ the dimensionless distance from the bottom, $\mathrm{u}_{*}$ the shear velocity, $\kappa$ the Von Karman constant equal to $0.4, \mathrm{k}_{\mathrm{s}}$ the equivalent sand grain roughness and $\mathrm{B}_{\mathrm{s}}$ the integration coefficient equal to 8.5 .

Fig. 9 show examples of results obtained with both Ub-flow configurations: instantaneous velocity profiles and mean velocity profiles in the vicinity of the sensor. Different measurements (with different colors) correspond to 5 successive data acquisitions with 5 min interval. Three different hydraulic conditions (at different dates) are considered in Fig. $9 \mathrm{a}, \mathrm{b}$ and $9 \mathrm{c}$. Some first observations can be made with these preliminary results: 


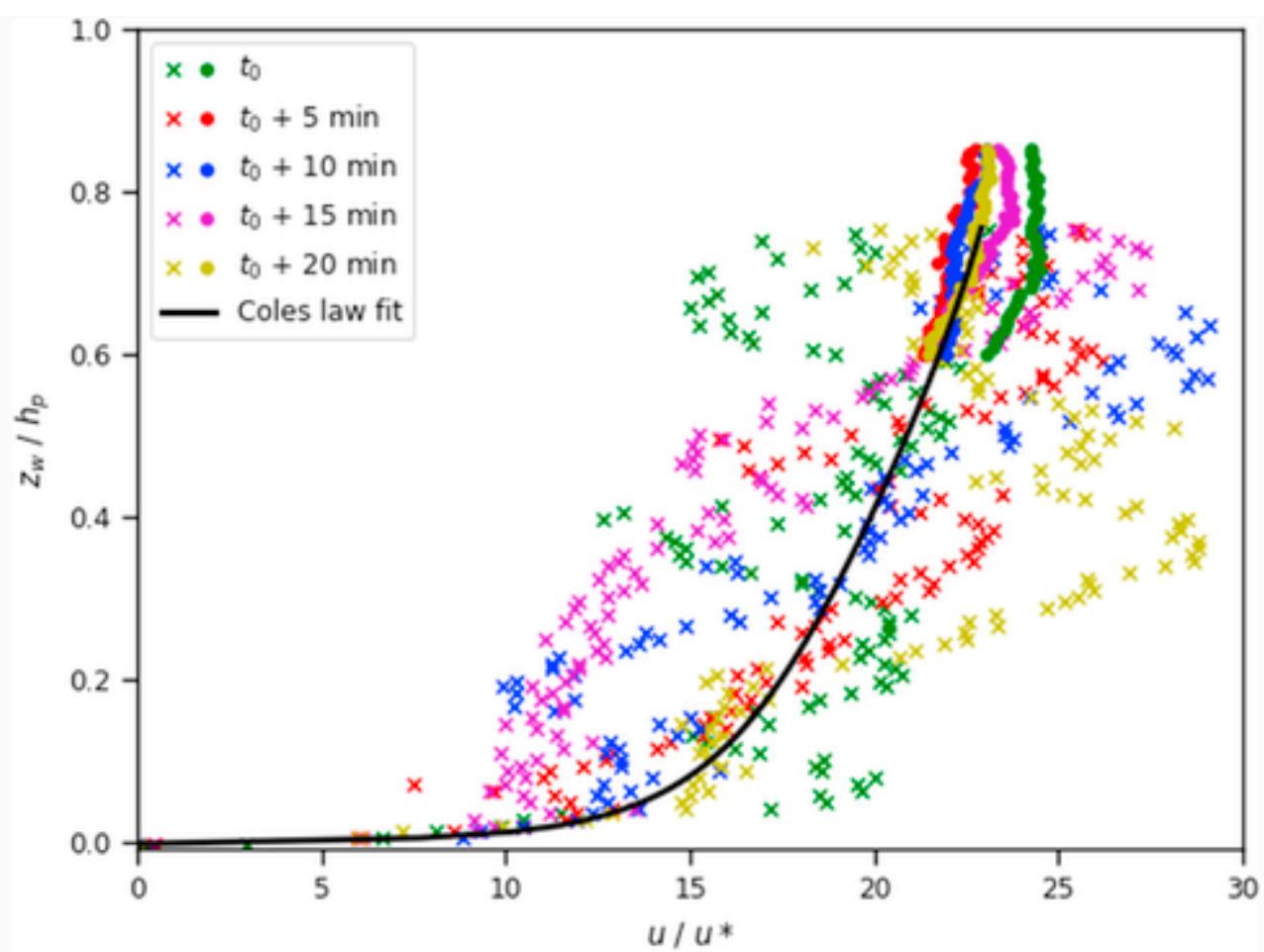

(a)

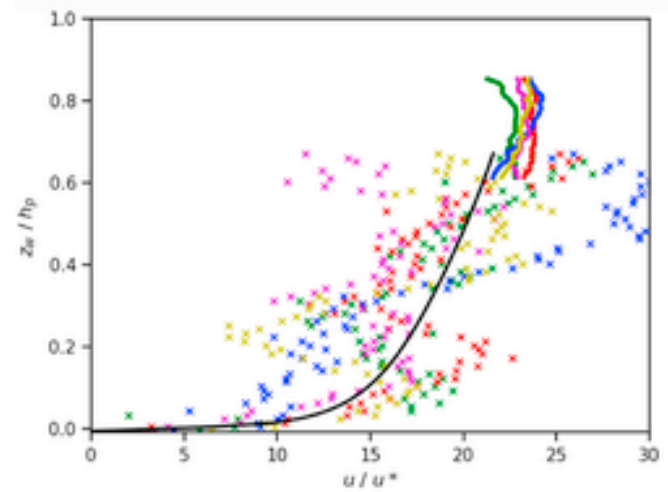

(b)

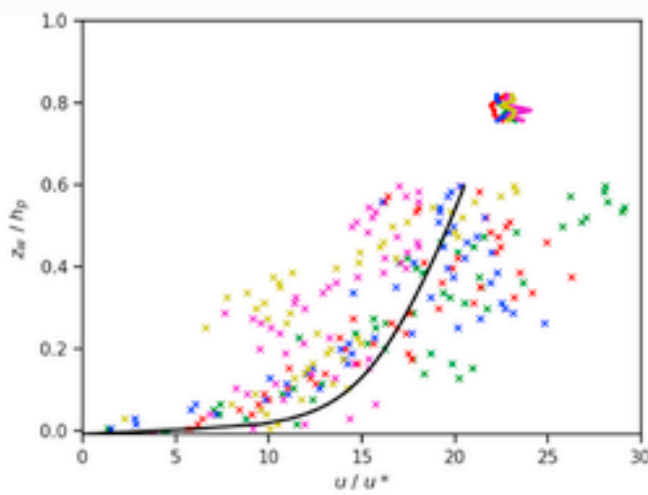

(c)

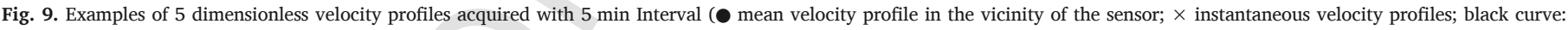

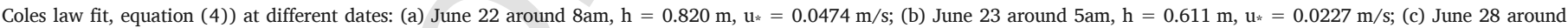
$6 \mathrm{am}, \mathrm{h}=0.497 \mathrm{~m}, \mathrm{u}_{*}=0.0115 \mathrm{~m} / \mathrm{s}$.

- for the instantaneous velocity profiles, important fluctuations are observed both considering a single profile and between the 5 successive profiles obtained at $\mathrm{t}_{\mathrm{o}}, \mathrm{t}_{\mathrm{o}}+5 \mathrm{mn}, \mathrm{t}_{\mathrm{o}}+10 \mathrm{mn}, \mathrm{t}_{\mathrm{o}}+15 \mathrm{mn}$ and $\mathrm{t}_{\mathrm{o}}+$ $20 \mathrm{mn}$. It is characteristic of flow velocity in a real river not as controlled as in a laboratory channel. However a good adjustment can be obtained with equation (4) allowing to evaluate the shear velocities for example;

- a good agreement can be found between instantaneous velocity profiles and mean velocity profiles in the vicinity of the sensor;

- the measurements allow characterizing the various hydraulic conditions of the river.

Notwithstanding, Fig. 10a shows that for a given water level and a rather steady situations, the profiles present a good repetitivity. On the other hand, Fig. 10b shows that some hysteresis can be observed between an almost steady situation and a water case when the water level decreased after a rainy day.
Velocity profiles are commonly obtained with profilers because they are a good tool to calculate river discharges. However, there is few profiles published in the literature as pointed by Song et al. [45], and those which are presented may be far from the theory, either the logarithmic or the power laws. The profiles of Figs. 9 and 10 are presenting fluctuations due to the complexity of a real flow but they are similar to those presented by Despax [46] in rivers. This author has also observed hysteresis that confirms the necessity to measure both the water level and the velocity to handle the hydraulics of this site. Moreover, the profiles presented in Fig. 10 present the same complex pattern that the profiles obtained by Franca et al. [47] in a lowland river of Switzerland.

\subsection{Usefulness of the camera}

A last point considering monitoring is the robustness of the set-up to natural or anthropic hazards and the general survey of the set-up. An incident occurred during the Miquel storm (June 5, 2019) that has generated a punctual flood of the river. Abnormal behaviors were thus observed on the data and the incident 


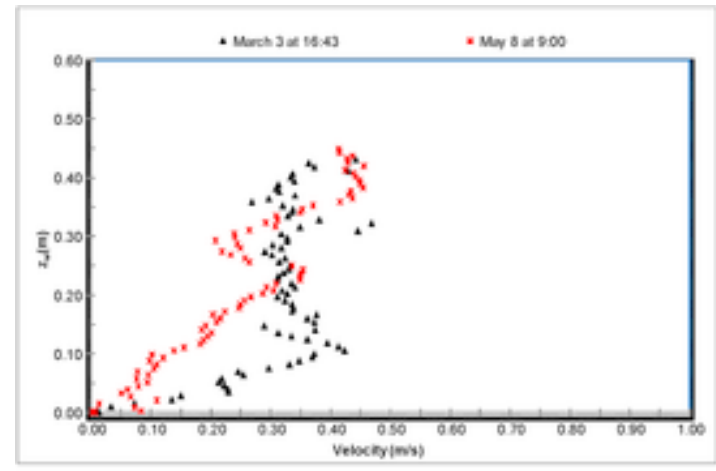

(a)

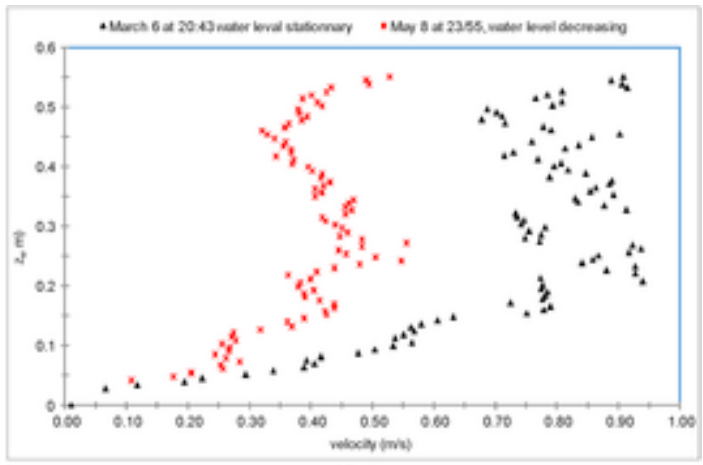

(b)

Fig. 10. Examples of instantaneous velocity profiles.

was confirmed thanks to the supervision camera (Fig. 11): a dead tree has twisted the set-up.

The Aurence river flows through a quiet and wooded valley mainly used by hikers and cyclists but there is no longer any real activity so the maintenance of the banks remains limited. Finally, the technical team has been able to repair it as soon as the water level has decreased enough to allow safe operation (Fig. 12). Efforts are done to obtain a more regular preventive cleaning in the future.

\section{Conclusions}

Scouring is a major risk for civil engineering structures and the complexity of the phenomena justifies monitoring real sites. It could thus both help to prevent major failures and to have a better understanding of scouring processes. To fully observe these processes, this monitoring should not only include bathymetric (or depth) and water level measurements (like various classical monitoring e.g. for offshore structures), but also velocity profile acquisition in order to have a complete observation of scour processes among time.

The innovative in situ monitoring device presented in this paper show that such complex instrumentation is now possible thanks to the progress of sensors, including acoustics. Several key elements of such complex projects of instrumentation have been listed: adaptation to the site and definition of the requirements and constrains, low intrusiveness, robustness of the device and the structure, remote access and surveillance ... in relation with the cost and the objectives of the desired monitoring. These apparatus already allow following the various hydraulic conditions (flow depth, velocity profile ...) and the local response of the sediments (scour/erosion or deposit) with a high acquisition frequency, especially in comparison with annual survey.
These first observations are very encouraging for the future data exploitation as flow characteristic can be extracted from the measurements. Further works will include:

- systematic evaluation and comparison of flow characteristics (mean characteristics as presented but also fluctuations as enabled by the instantaneous measurements),

- analysis of water level, water depth and sediment level and crossed study of all these properties and their evolution in relation with the site and its environment.

- improvement of automatic data treatments, measurements and evaluation of various important flow parameters such as the shear velocity,

The crossed study of all these parameters in relationship with the specific site environment characteristics will then allow increasing our knowledge of in situ scour processes.

\section{Funding}

This research was funded by Agence Nationale de la Recherche (French National Research Agency) within the project SSHEAR ANR-2014-CE03-0011.

\section{Uncited reference}

[44].

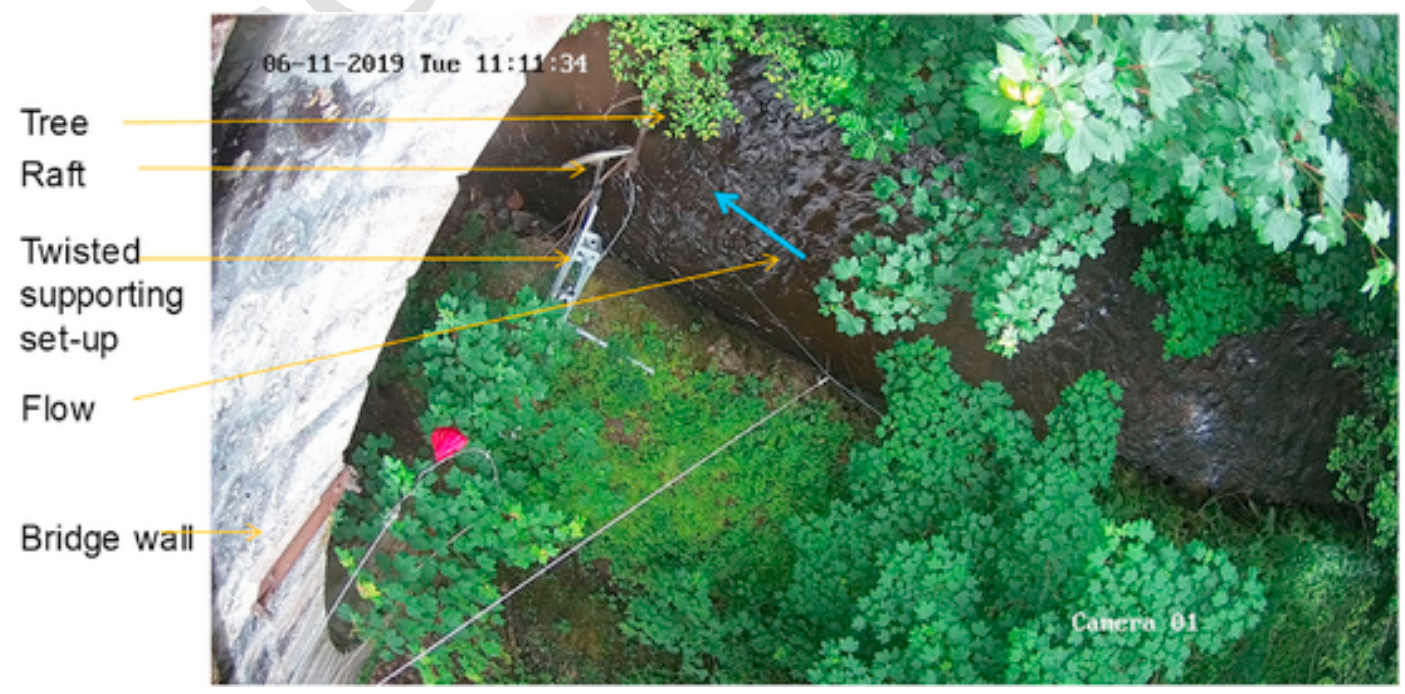

Fig. 11. View from the video camera. 


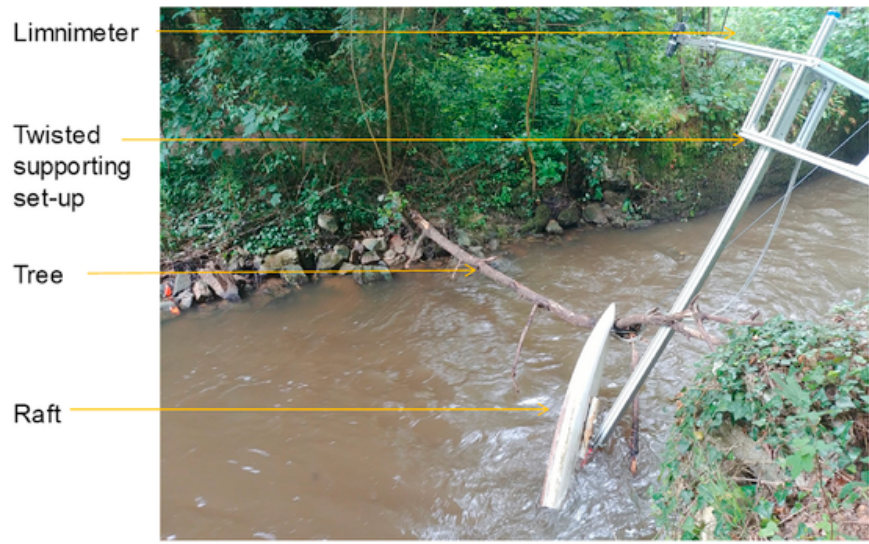

Fig. 12. View from the bank before reparation work.

\section{Declaration of competing interest}

The authors declare that they have no known competing financial interests or personal relationships that could have appeared to influence the work reported in this paper.

\section{Acknowledgments}

The authors thank Carlos Minatchy, Fabien Szymkiewicz of IFSTTAR Marne la Vallée (France) for their contribution to the in situ interventions, Marck Cheetham, Yannick Della Longua and SNCF Réseau staff in Limoges (France) for their safety and technical support related to river experiments, the members of the "unite Risques hydrauliques" of the Direction territoriale Normandie-Centre (site de Blois) of the Cerema for providing the bathymetry (Fig. 3), the laboratory Saint Venant in Chatou (France) for providing channels to conduct sensors testing and Emma Florens from Railenium for conducting them.

\section{References}

[1] A Durand Claye, A., Expériences sur les affouillements; Ann. des Ponts et Chaussées, 1er semestre, 1873, p. 467 (in French).

[2] H N C Breusers, G Nicollet, H W Shen, Local scour around cylindrical piers, J. Hydraul. Res. 15 (3) (1977) 211-252.

[3] J Chabert, P Engeldinger, Étude des affouillements autour des piles de ponts, Laboratoire National d'Hydraulique, Chatou, France, 1956 (in French).

[4] E M Laursen, A Toch, Scour Around Bridge Piers and Abutments, Iowa Highways Research Board, Ames, IA, 1956.

[5] B W Melville, A J Sutherland, Design method for local scour at bridge piers, J. Hydraul. Eng. (1988) 1210-1226.

[6] S Dey, Time-variation of scour in the vicinity of circular piers, Proc. Instn Civ, Engrs Wat., Marit. \& Energy, 1999136 (June) (1999) 67-75.

[7] M Gauthey, Traité de la construction de Ponts, Editions Navier, Paris, 1832 (in French).

[8] Ministère des Transports, DGTI, Instruction technique pour la surveillance et l'entretien des ouvrages d'art, ondations en site aquatique, 1979 (in French).

[9] Setra - Technical guide, Watercourses and Bridges, 1979 (in French).

[10] J R Temez Pelaez, Control de la erosion fluvial en puentes, Ministerio de Obras Publicas y transportes, 1988 (in Spanish).

[11] G Hoffmans, H J Verheij, Scour Manual, Balkema edition, Rotterdam, 1997.

[12] R P W May, J C Ackers, A M Kirby, Manual on Scour at Bridges and Other Hydraulic Structures, CIRIA, United Kingdom, 2002, p. 225.

[13] A Guitelman, A del Valle Leiva, A S Bebczuk, Comparacion de métodos de calculo de erosion en puentes, III Congreso Iberoamericano sobre control de la erosion y los sedimentos, Buenos Aires, 2006 (in Spanish)

[14] D M Sheppard, H Demir, B Melville, Scour at Wide Piers and Long Skewed Piers, National Cooperative Highway Research Program Rep, 682, Transportation Research Board, Washington, DC, 2011.

[15] L A Arneson, L W Zevenbergen, P F Lagasse, P E Clopper, Evaluating Scour at Bridges, Report No. FHWA-HIF-12-003 HEC18, 2012.
[16] Department of Transport and Main Roads, Bridge Scour Manual, Queensland government, 2013.

[17] L Hamill, Bridge Hydraulics, E\&FN Spon Editors, 1999, p. 367 London \& New York.

[18] B W Melville, S E Coleman, Bridge Scour, 562 pages, Water Resources ublications, LLC, 2000 1_887 201_18_1.

[19] D Sheppard, B Melville, Demir, H. Evaluation of existing equations for local scour at bridge piers, J. Hydraul. Eng. 140 (1) (2013).

[20] R Ettema, G Constantineescu, B Melville, Flow-field complexity and design estimation of pier-scour depth: sixty years since laursen and toch, J. Hydraul. Eng. 143 (9) (2017) 03117006.

[21] M R Simpson, Discharge Measurements Using a Broad-Band Acoustic Doppler Current Profiler, Open File Rep. 01-1, U.S. Geol. Surv., Sacramento, Calif, 2001, p. 123.

[22] G Tapia Rodriguez, J P Molina Aguilar, G B Perez Moarales, A A Torers Acosta, Metodología para la medición de la velocidad de flujo en un río en el diagnóstico de la socavación en pilas de un puente, utilizando un dispositivo electrónico, Publicación Técnica No. 356, Instituto mexicano del transporte, 2012 (in Spanish).

[23] M C Forbe, D M McCann, M R Clark, K J Broughton, P J Fenning, A Brown, Radar measurement of bridge scour, NDT\&E International 32 (1999) 481-492.

[24] J D Schall, P Davies, Instrumentation for Measuring Scour at Bridge Piers and Abutments TR News 203, 1999.

[25] L Prendergast, D Hester, K Gavin, J O'Sullivan, An investigation of the changes in the natural frequency of a pile affected by scour, J. Sound Vib. 332 (25) (2013) 6685-6702.

[26] M Samizo, S Watanabe, T Sugiyama, K Okada, Evaluation of the structural integrity of bridge pier foundations using microtremors in flood conditions, Scour and Erosion (2010) 824-833.

[27] M Shinoda, H Haya, S Murata, Nondestructive Evaluation of Railway Bridge Substructures by Persussion Test, Fourth international conference on scour and erosion, Tokyo, Japan, 2008.

[28] O Taylor, et al., Remote Scour Assessment Using Infrasound, ICSE6-045, Paris, 2012.

[29] Hunt, Monitoring Scour Critical Bridges, A Synthesis of Highway Practice, 396, NCHRP Synthesis, 2009, https://trid.trb.org/view/908559.

[30] J L Briaud, S Hurlebaus, K A Chang, C Yao, H Sharma, O-Y Yu, C Darby, B E Hunt, G R Price, Realtime Monitoring of Bridge Scour Using Remote Monitoring Technology. Technical Report, 2011.

[31] A A Khan, S Huriye, H S Atamturktur, Real Time Measurement of Scour Depths Around Bridge Piers and Abutments, Final Report, Report No. FHWA-SC-14-05 HEC20, 2015.

[32] M Fisher, M Chowdhury, A Khan, S Atamturktur, An evaluation of scour measurement devices, Flow Meas. Instrum. 33 (2013) 55-67.

[33] L J Prendergast, K Gavin, A review of bridge scour monitoring techniques, J. Rock Mech. Geotech. Eng. 6 (2) (2014) 138-149.

[34] C Wang, X Yu, F Liang, A review of bridge scour: mechanism, estimation, monitoring and countermeasures, Nat. Hazards 87 (2017) 1881-1906.

[35] C Chevalier, F Larrarte, F Schmidt, D Pham-Van-Bang, E Durand, P Gondret, S de la Roque, M Cheetham, M Hosseingholian, Research program SSHEAR: recent advances on the understanding and the control of scour phenomena, Ninth International Conference on Scour and Erosion (ICSE), Nov. 5-8, 2018, 2018 (Taipei, Taiwan).

[36] B Salavati, M Cheetham, L Mellal, A Siduron, C Pams Capoccioni, Development of an integrated approach to select structures at risk from scour erosion, GEORAIL International Symposium, 2017 (in French).

[37] E Le Barbu, F Larrarte, Acoustic profilers and urban pollutant fluxes, European Journal of Environmental and Civil Engineering 14 (Issue 5) (2010) 637-651, doi:10.3166/EJECE.14.637-651.

[38] N Hemmerle, J J Randrianarimanana, C Joannis, F Larrarte, Hydraulics and deposit evolution in sewers, Symp. On Ultrasonic Doppler Methods for Fluid Mech. and Fluid Eng.-9. 9-12, 2014 (Strasbourg).

[39] F Larrarte, E Szturycz, L Lebouc, B Riochet, New technique for continuous monitoring of sediment height, Flow Meas. Instrum. 49 (June) (2016) 40-45, doi:10.1016/j.flowmeasinst.2016.04.005.

[40] S Fisher, Développement d'une instrumentation ultrasonore pour la mesure des vitesses des liquides au-delà de la limite de Nyquist par une approche spectrale Thèse de doctorat, Université de Strasbourg, 2004, p. 213 (in French).

[41] ISO, Norme NF EN ISO 748:2009. Hydrométrie - Mesurage du débit des liquides dans les canaux découverts au moyen de débitmètres ou de flotteurs, 2009, p. 47.

[42] J Nikuradse, Laws of flow in rough pipes, Translation in National Advisory Committee for Aeronautics, Technical Memorandum 1292, NACA, Washington, 1950, p. 62.

[43] D Coles, The low of the wake in the turbulent boundary layer, J. Fluid Mech. 1 (1956) 191-226.

[44] ISO, ISO/TR 24578:2012, Hydrometry - acoustic Doppler profiler - method and application for measurement of flow in open channels, 2012

[45] S Song, B Schmalz, N Fohrer, Improved structure of vertical flow velocity distribution in natural rivers based on mean vertical profile velocity and relative water depth, Nord. Hydrol (2017).

[46] A Despax, Incertitude des mesures de débit des cours d'eau au courantomètre. Amélioration des méthodes analytiques et apports des essais interlaboratoires, (Uncertainty in discharge measurements using the velocity-area method Ph.D. thesis, Improvement of Analytical Methods and Contribution of Field Inter-Laboratory Experiments, Université Grenoble Alpes, 2016 (in French).

[47] M J Franca, R M L Ferreira, U Lemmin, Parameterization of the logarithmic layer of double-averaged streamwise velocity profiles in gravel-bed river flows, Adv. Water Resour. 31 (2008) 915-925. 